International Journal of Engineering \& Technology, $9(2)(2020) 487-493$
International Journal of Engineering \& Technology
SPC
Website: www.sciencepubco.com/index.php/IJET
Research paper

\title{
Enhancement of bio-methane production yield from rumen digesta with biodegradable kitchen wastes by co-digestion process
}

\author{
Muhammad Rashed Al Mamun ${ }^{1 *}$, Mahdi Muhammed ${ }^{1}$, Nadira Sultana Urme ${ }^{1}$, Md. Janibul Alam Soeb ${ }^{1}$ \\ ${ }^{1}$ Department of Farm Power and Machinery, Faculty of Agricultural Engineering and Technology, Sylhet \\ Agricultural University, Sylhet-3100, Bangladesh \\ *Corresponding author E-mail: rashed.fpm@sau.ac.bd
}

\begin{abstract}
The study was investigated to enhance biogas production from rumen digesta by anaerobic co-digestion process. The experiment was carried out in $3300 \mathrm{~mL}$ digester. The mixing ratio of rumen digesta and water used was 1:1 in 40 days Hydraulic Retention Time (HRT). Produced gas was measured by volumetric water replacement method. In phase-1, the maximum biogas generation from digesta of chicken and goat, cow and chicken, cow and goat, and co-digestion of four substrates (C:CH:G:V) were $65,1230,37$ and $375 \mathrm{~mL} / \mathrm{d}$ at $17^{\text {th }}, 14^{\text {th }}$, $26^{\text {th }}$ and $13^{\text {th }}$ day respectively. The average biogas production was found from these samples were $20,340,16$ and $113 \mathrm{~mL}$. In phase-2, the maximum biogas generation from cow, goat and chicken, cow, chicken and vegetable waste and cow, goat and vegetable waste were respectively 66,80 and $64 \mathrm{ml} / \mathrm{d}$ at $19^{\text {th }}, 23^{\text {rd }}$ and $27^{\text {th }}$ day. The average biogas generation were found from these samples $22,32 \mathrm{and} 19 \mathrm{~mL}$. The comparative data shows, biogas production is higher with cow and chicken wastes in both the phases mixed with vegetable waste. Thus, it is suggested that the study which gave maximum yield of biogas production from co-digestion process might be met the future energy demand.
\end{abstract}

Keywords: Biogas; Co-Digestion Process; Fossil Fuel; Renewable and Non-Renewable Energy; Rumen Digesta.

\section{Introduction}

On the last decades, anaerobic digestion is used as a process to treat organic solid wastes became more and more frequent. The reason of this new tendency for the treatment of solid wastes can be explained considering mainly three factors [1-3]: i) the need to apply a process to the disposal of organic solid wastes more environmental friendly than landfills as requested by the latest rules concerning the environmental protection in many countries in the world; ii) the opportunity to obtain a renewable fuel called biogas from this process is an alternative to fossil ones; iii) the advantage of this process is relatively low costs in starting up and management.

The exhaustion of fossil fuels and the global warming situation are strong motivating factors for alternatives fuels research. Many countries are showing their interest in sustainable renewable energy sources such as; geothermal power, wind power, small-scale hydropower, solar energy, biomass energy, tidal power, and wave power [4]. Biomass energy is environmentally friendly and requires less production energy [5]. Various biomasses derived from the carbonaceous waste of human, animals and natural resources could be utilized as renewable energy resources [6]. Solutions to waste problems such as food waste and manure including gasification, pyrolysis and plasma technologies (incineration) of solid wastes have been developed [7]. These technologies involve the combustion of organic waste at elevated temperatures in the absence of oxygen. These technologies require a lot of energy to operate, and some facilities consume more energy than what they can produce [7]. Microorganisms transform biodegradable substrates into biogas and stabilized solid residues could be a better option [8]. Generally fossil fuels contain high percentages of carbon and include petroleum, coal, and natural gas. Fossil fuel ranges from volatile materials with low carbon to hydrogen ratios like methane, to liquids like petroleum, to nonvolatile materials composed of almost pure carbon, like anthracite coal. Methane can be found in hydrocarbon fields either alone, associated with oil, or in the form of methane clathrates. The use of fossil fuels is raising serious environmental concerns of carbon dioxide is produced per year. Carbon dioxide is a greenhouse gas which increases the radioactive forcing and contributes to the global warming. A global movement towards the generation of low-carbon renewable energy is underway to help reduce global greenhouse gas emissions.

Renewable energy sources are an effective and efficient solution to mitigate this alarming problem. Renewable energy source are those sources which are naturally replenished on human timescale such as wind, sun, rain, wave. To produce renewable energy, rumen digesta may be useful source. Rumen digesta is mainly animal waste. The reticular rumen is a large chamber in which ingested feed is first subjected to microbial digestion. Disposal system of rumen waste may create environmental pollution, result in health hazard to human due to the presence of millions of microorganisms and also causes water pollution by entering into rivers, streams and other local sources. It is also responsible for greenhouse effect because of conversion into methane and carbon dioxide. Methane gas is 23 times more potent greenhouse 
gas than carbon dioxide. Pathogenic organisms are also found in slaughterhouse wastes including Clostridium perfringens, vibrio sp. The environmental pollutions can be prevented by recycling rumen digesta. One of the key methods to recycle rumen digesta is to produce biogas as a renewable energy source and can also produce bio-fertilizer and feeder by recycling rumen digesta.

Biogas can be defined as a mixture of different gases which are produced by the breakdown of organic matter in the absence of oxygen in closed system is called an anaerobic digester, biodigester or a bioreactor. Biogas a gaseous mixture which is mainly composed of methane and carbon dioxide through the concerted action of a close-knit community of bacteria. The process of biogas production is divided into four steps [9]. Hydrolysis is a reaction with water. Acid and base are used to accelerate the reaction, and this is also occurring in enzymes. The cellulose, starch, and simple sugars can be broken down by water and enzymes. During acidogenesis, soluble monomers are converted into small organic compounds, such as short chain (volatile) acids (propionic, formic, lactic, butyric, succinic acids, ketones (glycerol, acetone), and alcohols (ethanol, methanol). The acidogenesis intermediates are attacked by acetogenic bacteria; the products from acetogenesis include acetic acid, $\mathrm{CO}_{2}$, and $\mathrm{H}_{2}$. The last phase of anaerobic digestion is the methanogenesis phase. Several reactions take place using the intermediate products of the other phases, with the main product being methane.

There are many studies available on biogas production from cow dung, solid waste. Al Mamun and Torii conducted an experiment to regulate the potential biogas production from different mixing ratios of vegetable, fruit \& cafeteria waste [10, 11]. Rouf et al. conducted an experiment to know the potential of biogas production from slaughter house waste and to know the optimum condition for production [12]. Peyman Abdeshahian et al. studied on the potential of biogas production from farm animal waste [13]. But there are few remarkable studies on enhancement of bio-methane production from rumen digesta by co-digestion process. A study focused on waste reduction that comes from slaughter house and also investigated the possibility of biogas production from rumen waste. Salleh et al. found that Biogas production can be improved using dairy manure and rumen fluid [14]. Opurum et al. investigated on production of biogas from fish pond effluent supplemented with cow blood [15]. Manimuthu et al. conducted an experiment to know the effect of Agar waste on biogas production from the co-digestion of rumen waste [16]. Budiyono et al., demonstrated the ability of biogas production from slaughter house waste (rumen fluid, rumen digesta, cow dung) [17]. According to Ambar Perti winingrum et al. addition of rumen fluid reduces the time which is required for the initial phase of decomposition (hydrolysis and acidogenesis) compare with methane formation phase [18]. D.A. Putri et al. use cow manure coupled with rumen fluid and water for production of biogas. The study showed the influence of manure, rumen and water in biogas production [19]. Yasunori Baba et al. conducted an experiment with rumen fluid. According to experiment, pretreatment of waste paper with rumen fluid increase methane yield [20]. Sunarso et al. studied on the effect of rumen fluid of animal ruminant to increase biogas production from cattle manure at mesophilic condition [21]. This study focusses on enhancement of bio-methane production as a renewable energy source by co-digestion process of rumen waste with kitchen waste to control environmental pollution.

\section{Materials and metods}

\subsection{Collection of raw material}

Rumen waste of cow used for the experiment was collected from slaughterhouse of Shibganj and Mirabazar. Chicken waste was collected from the slaughter house of Eidgah and Baluchor bazaar. Rumen waste of goat was collected from slaughterhouse of Mirabazar. Vegetable waste was collected from the Baluchor bazaar. The collected raw material was stored at $4^{\circ} \mathrm{C}$ and used for experiment. Rumen digesta contain some undigested food such as grass, straw, grain.

\subsection{Sample preparation}

For the first phase, rumen waste of cow, chicken, goat was weighted and made four sample for fermentation. Four mix samples of two types of rumen waste was prepared and mixed in the ratio of waste of chicken: goat 1:1, cow: chicken 1:1, cow: goat 1:1. A mix sample of four types of rumen waste was prepared and mixed in the ratio of Cow:Chicken: Goat:Vegetable (C:CH:G:V) 1:1:1:1 were diluted with water and mixed properly to obtain homogenous condition. $\mathrm{P}^{\mathrm{H}}$ of sample was measured of 6.6, 6.8, 6.6, and 6.9 for cow, chicken, goat and mixture of cow, chicken, goat rumen digesta with rumen fluid respectively.

Table 1: Amount of feedstock's used in the reactor

\begin{tabular}{|c|c|c|c|}
\hline Reactor & Rumen waste (Kg) & Water (L) & Amount of material $(\mathrm{Kg})$ \\
\hline \multicolumn{4}{|l|}{ Phase 1} \\
\hline R1(Chicken + Goat) & $0.68 * 2$ & 1.36 & 2.72 \\
\hline R2 (Cow + Chicken) & $0.68 * 2$ & 1.36 & 2.72 \\
\hline R3 (Cow + Goat) & $0.68 * 2$ & 1.36 & 2.72 \\
\hline $\mathrm{R} 4($ Cow + Chicken + Goat + Vegetable $)$ & $340 * 4$ & 1.36 & 2.72 \\
\hline \multicolumn{4}{|l|}{ Phase 2} \\
\hline R5 ( Cow + Goat + Chicken $)$ & $0.45 * 3$ & 1.36 & 2.72 \\
\hline R6 ( Cow + Chicken + Vegetable) & $0.45 * 3$ & 1.36 & 2.72 \\
\hline R7 (Cow + Goat + Vegetable $)$ & $0.45 * 3$ & 1.36 & 2.72 \\
\hline
\end{tabular}

In second phase of the experiment, rumen waste of cow, chicken, goat was weighted and made three samples for fermentation. Three mix sample of three types of rumen waste was prepared and mixed in the ratio of waste of cow:goat:chicken 1:1:1, cow: chicken: vegetable 1:1:1, cow: goat: vegetable 1:1:1. $\mathrm{P}^{\mathrm{H}}$ of sample was measured of 6.8 for cow, 6.2 for chicken, 6.8 for goat, 7.3 for vegetable. The size of beaker is $3300 \mathrm{~mL} .80 \%$ of beaker $(2.72 \mathrm{~kg})$ was filled with material $1: 1$ which is $0.68 \mathrm{~kg}$ and $0.45 \mathrm{~kg}$ each for first and second phase. Kitchen substrates were blended the substrates for homogeneous mixture by making small particle size in $0.5 \mathrm{~mm}$ to $10 \mathrm{~mm}$ for both phases with the help of electric blending machine. The quantity of rumen digest used in reactors is shown in Table 1.

\subsection{Experimental set up}

The lab scale experimental set up was started by using four $3300 \mathrm{~mL}$ digester, water cum chamber and water collector for every observation. The temperature range was $25^{\circ} \mathrm{C}$ to $30^{\circ} \mathrm{C}$ during the study period. The digester related to water chamber with a 12 mm hose pipe. Pipe was used to permit produced gas to flow from digester to water chamber. Gas creates pressure in water chamber and forced same volume of water to flow to water collector through another $10 \mathrm{~mm}$ hose pipe. One end of the gas pipe was connected to the top of digester with a glass 
tube and other part was connected to the top of the water chamber. One part of water pipe was connected to the top of the water chamber and other part of pipe was connected to the water collector. A gas control valve was attached with hose pipe to control the flow of produced gas. Other material used for that experiment include thermometer, $\mathrm{P}^{\mathrm{H}}$ meter, glass tube, gas pressure gauge, gas flow control valve, graduated plastic bucket, beaker, hosepipe. Biogas production was monitored during study period. The data of 40 days Hydraulic Retention Time (HRT) was recorded. The schematic diagram of experimental set up is shown in Fig. 1.

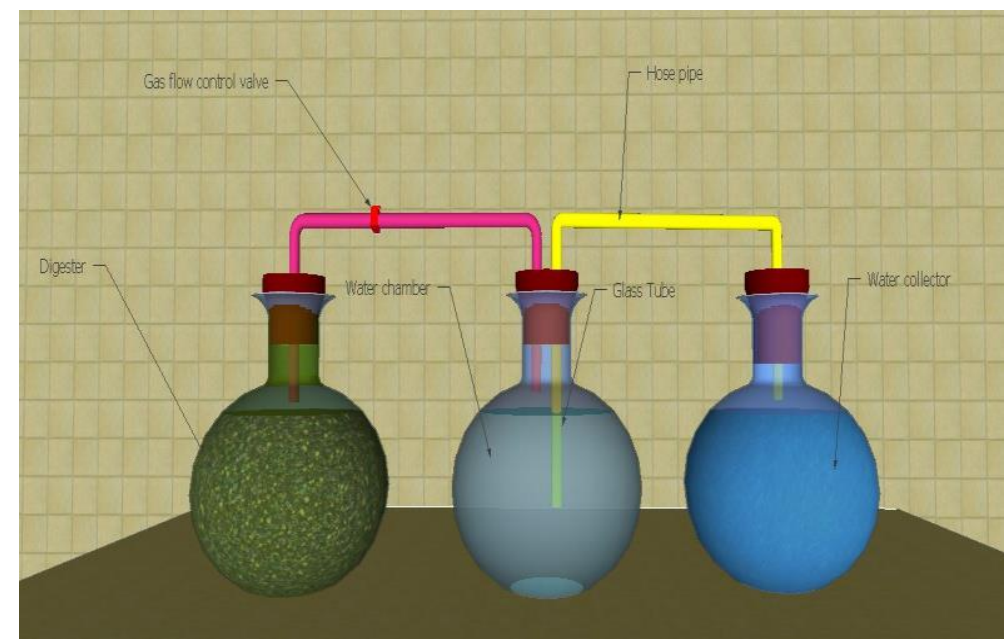

Fig. 1: Schematic Diagram of Experimental Set Up.

\subsection{Data collection of produced gas}

In this experiment the amount of produced gas was measured by water displacement method. Data was collected every day at $12 \mathrm{pm}$ in the Agricultural and Biosystems Engineering Lab at Sylhet Agricultural University. Slurry was Pulverized inside biogas digester by hand shaking the reactor to stimulate bacterial activity and release the biogas avoiding sedimentation of the fed materials under the biogas reactor during the data collection of 40 days Hydraulic Retention Time.

\subsection{Observation}

In the first phase experiment (1), four observations were started after filling the digester with rumen waste of chicken and goat, cow and chicken, cow and goat, and mixed rumen waste. After filling, digester was left for anaerobic digestion and gas was started to produce from second operating day and it was almost finished at $39 / 40^{\text {th }}$ digestion day. Produced gas was permitted to flow through pipe into water chamber and forced same volume of water to flow into water collector through hose pipe. Produced gas was measured directly through the measurement of the same volume of displaced water. Observation was continued till the flow of displaced water was stopped.

In the second phase experiment (2), three observations were started after filling the digester with rumen waste of cow, goat and chicken, cow, chicken and vegetable, and cow, goat and vegetable. After filling, digester was left for anaerobic digestion and gas was started to produce from first operating day and it was almost finished at 39/40 water was stopped following the same procedure of first phase experiment.

\subsection{Analytical method}

The kitchen wastes were blended using Sahara pride mixer grinder (750W, RTG 30 MIN, 18000 RPM, VK Group of Industries, INDIA). The samples were taken and measure $\mathrm{p}^{\mathrm{H}}$ by $\mathrm{p}^{\mathrm{H}}$ tester (HI98107, HANNA Instruments, Inc. Romania). Thermometer (TP300, China) was used to keep record daily temperature of study period as well as daily ambient temperature of the environment. Temperature range of TP300 thermometer is $-50^{\circ} \mathrm{C} \sim+300^{\circ} \mathrm{C}$. Microsoft Excel 2013 software was used to make the graphical analysis.

\section{Results and discussion}

\subsection{Biogas production profile}

Fig. 2, represents the daily production of biogas from rumen digesta and kitchen waste in phase 1. Under 40 days Hydraulic Retention Time (HRT), the production starts from the first operating day due to the rapid decomposition of undigested feedstock of chicken and goat. Production was gradually increased from the $5^{\text {th }}$ day to $17^{\text {th }}$ day. Then production was decreased due to temperature fall and digestion of slurry. Maximum gas production was $65 \mathrm{~mL} / \mathrm{d}$ which was recorded in $17^{\text {th }}$ day of study period. The average rate of gas production was 20 $\mathrm{mL} / \mathrm{d}$.

The highest production rate of biogas from cow and chicken rumen waste was $1230 \mathrm{~mL} / \mathrm{d}$ at $14^{\text {th }}$ day with high fluctuations due to $\mathrm{p}^{\mathrm{H}}$ and temperature variation under 40 days Hydraulic Retention Time (HRT). The average gas production was $340 \mathrm{~mL} / \mathrm{d}$. This study shows that the production of biogas from cow and chicken digesta was more than chicken and goat digesta. Although production does not start from the beginning day and production rate was very low compared to zero because rumen digesta of cow which also contain some undigested food such as grass, straw, grain which decomposed slowly which was indicated the upward trend of the graph after first 6 days. 


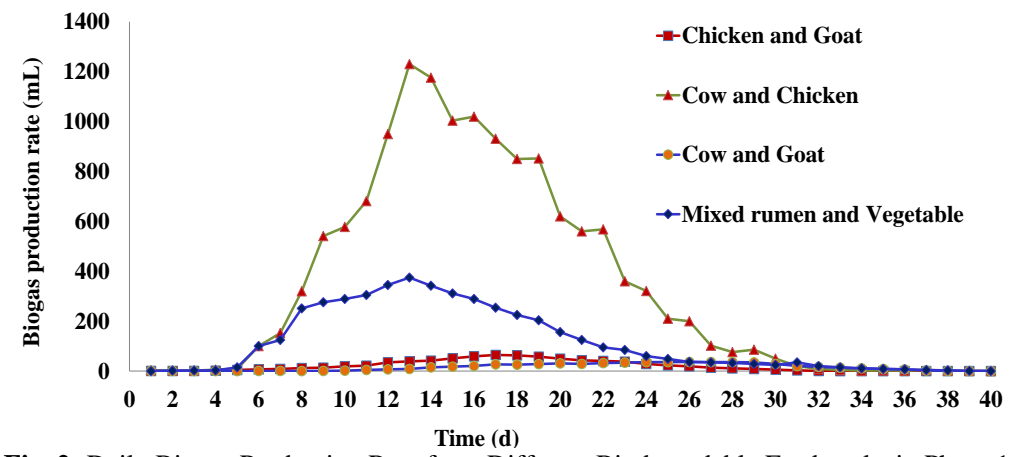

Fig. 2: Daily Biogas Production Rate from Different Biodegradable Feedstocks in Phase 1.

The results also showed that, the maximum production rate of biogas from cow and goat rumen waste was $37 \mathrm{~mL} / \mathrm{d}$ at $26^{\text {th }}$ day. After $29^{\text {th }}$ day of digestion period production decreased and continued to decrease up to $40^{\text {th }}$ day. The average rate of production was $16 \mathrm{~mL} / \mathrm{d}$. The undigested waste of cow needed more time to digest and undigested waste of goat needed less time to decompose as a result, at the beginning of retention period the biogas production rate was less.

Moreover, production of biogas from co-digestion of cow, chicken, goat and vegetables as shown in Fig. 2. Biogas production started from the $5^{\text {th }}$ operating day. Production was high at the first few days. Maximum production was $375 \mathrm{~mL} / \mathrm{d}$ obtained at the $13^{\text {th }}$ day. Rate of production varied with temperature. The average rate of biogas production was $114 \mathrm{~mL} / \mathrm{d}$. The general prediction is that production rate directly related with the growth of methanogenic bacteria, temperature and $\mathrm{p}^{\mathrm{H}}$. The investigation was observed that the biogas production rate was almost stabled from the $31^{\text {st }}$ day to $40^{\text {th }}$ day. The study result reveals that biogas production rate was not highly fluctuated over the digestion period.

Fig. 3. represents that the production rate of biogas from cow, goat and chicken waste. The production does not start from the beginning day and production rate was very low compared to zero because rumen digesta of cow contains some undigested feedstock such as grass, straw, grain which decomposed slowly. Under 40 days Hydraulic Retention Time (HRT), the highest gas production was $66 \mathrm{~mL} / \mathrm{d}$ at $19^{\text {th }}$ day with high fluctuations due to temperature variation. The average gas production was $22 \mathrm{~mL} / \mathrm{d}$.

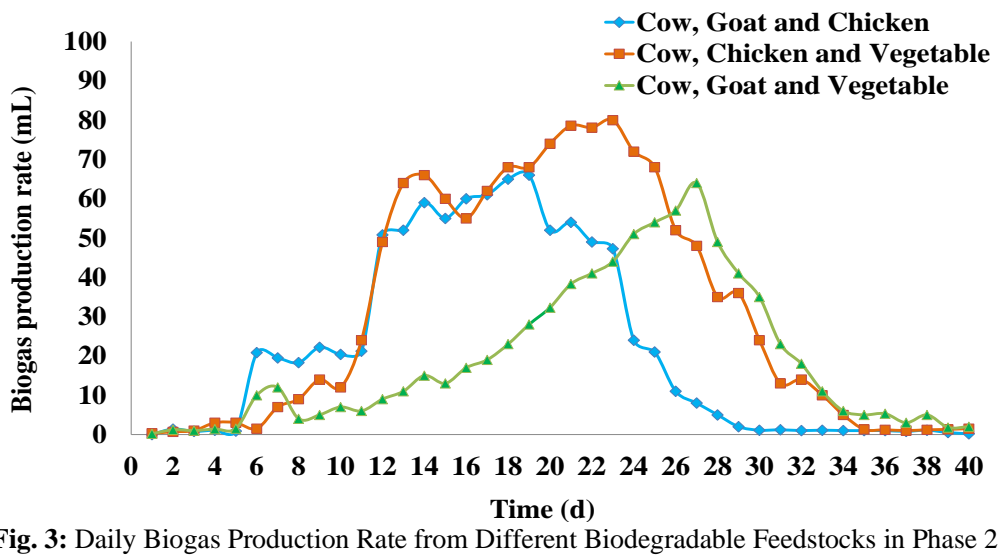

This experiment was found that the maximum production rate of biogas from rumen digesta of cow, chicken and vegetable waste was 80 $\mathrm{mL} / \mathrm{d}$ at $23^{\text {th }}$ day. After $23^{\text {th }}$ day of digestion period production was sharply decreased and continued to decrease during the study period. The average rate of production was $32 \mathrm{~mL} / \mathrm{d}$. At the beginning of retention period the biogas production rate was less. The investigation was observed that the biogas production rate was almost stabled from the $35^{\text {th }}$ day to $40^{\text {th }}$ day.

The maximum production of gas was $64 \mathrm{~mL} / \mathrm{d}$ was recorded in $27^{\text {th }}$ day of study period from cow, goat and vegetable waste as shown in Fig. 3. At the beginning of retention period the biogas production rate was less. The biogas production rate was gradually increased from the $1^{\text {st }}$ day to $7^{\text {th }}$ day. The average rate of production was $19 \mathrm{~mL} / \mathrm{d}$. The investigation was observed that the biogas production rate was almost stabled from the $34^{\text {th }}$ day to $40^{\text {th }}$ day due to the fluctuations due to temperature variation.

\subsection{Comparison profile of biogas generation}

Fig. 4, represents the difference in biogas production after every 10 days in first phase. This figure reveals that after 10 days production was low in every digester except in digester which was filled with cow and chicken rumen waste. The figure also shows that biogas production from cow and chicken rumen waste were increased in $2^{\text {nd }} 10$ days and then decreased in $3^{\text {rd }}$ and $4^{\text {th }} 10$ days because of the highly decomposed rate was occurred after 10 days. Production of gas from cow and goat rumen waste was decreased in $1^{\text {st }}, 2^{\text {nd }}$ and $4^{\text {th }} 10$ days compared with in $3^{\text {rd }} 10$ days. The figure shows that production of gas from mixed waste of cow, chicken, goat and vegetable were firstly high in $1^{\text {st }} 10$ days and gradually increased in $2^{\text {nd }} 10$ days because of co-digestion of three substrate ratio and vegetable waste i.e. protein, nitrogen increased production. When vegetable waste became digested fully production rate decreased in $3^{\text {rd }}$ and $4^{\text {th }} 10$ days. Figure also shows that highest gas produced from chicken and goat, cow and chicken, cow and goat and mixed rumen waste was 484, 931, 4, 340, and $2806 \mathrm{~mL} / \mathrm{d}$ in $2^{\text {nd }}, 2^{\text {nd }}, 3^{\text {rd }}$ and $2^{\text {nd }} 10$ days respectively. 


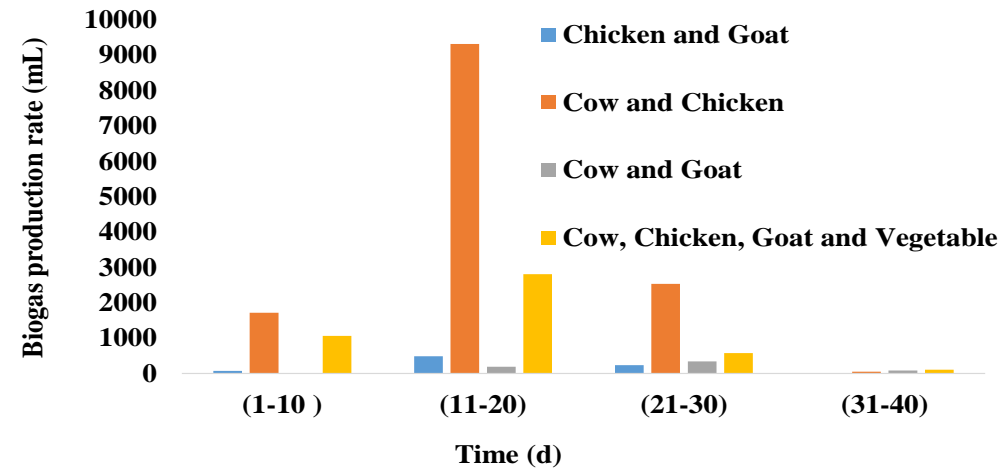

Fig. 4: Variation of Gas Production After Every 10 Days in Phase 1.

Fig. 5, represents the difference in biogas production after every 10 days in second phase. This figure reveals that after 10 days production was high in every digester except in digester which was filled with cow, goat and vegetable waste. The figure also shows that biogas production from cow, chicken and vegetable waste were increased in $2^{\text {nd }}$ and $3^{\text {rd }} 10$ days then decreased in $4^{\text {th }} 10$ days because of the highly decomposed rate was occurred after $4^{\text {th }} 10$ days. Production of gas from cow, goat and vegetable waste were decreased in $1^{\text {st }}$, and $4^{\text {th }} 10$ days and increased in $2^{\text {nd }}$ and $3^{\text {rd }} 10$ days. The Figure shows that production of gas from cow, goat and chicken were firstly less in $1^{\text {st }} 10$ days and gradually increased in $2^{\text {nd }} 10$ days because of co-digestion of three substrate ratio and vegetable waste gradually increased in $1^{\text {st }}$, $2^{\text {nd }}$ and $3^{\text {rd }} 10$ days i.e. protein, nitrogen increased production and gradually decreased in $3^{\text {rd }}$ and $4^{\text {th }} 10$ days for rumen digesta and $4^{\text {th }} 10$ days for kitchen waste means fluctuated over the retention time due to decomposed of feedstocks. The Figure also shows that highest gas produced from cow, goat and chicken, cow, chicken and vegetable and cow, goat and vegetable waste was $562,590,474 \mathrm{~mL} / \mathrm{d}$ in $2^{\text {nd }}, 2^{\text {nd }}$ and $3^{\text {rd }} 10$ days respectively. The comparative data shows that biogas production is higher with cow, goat and vegetable wastes in both the phases mixed with the chicken waste.

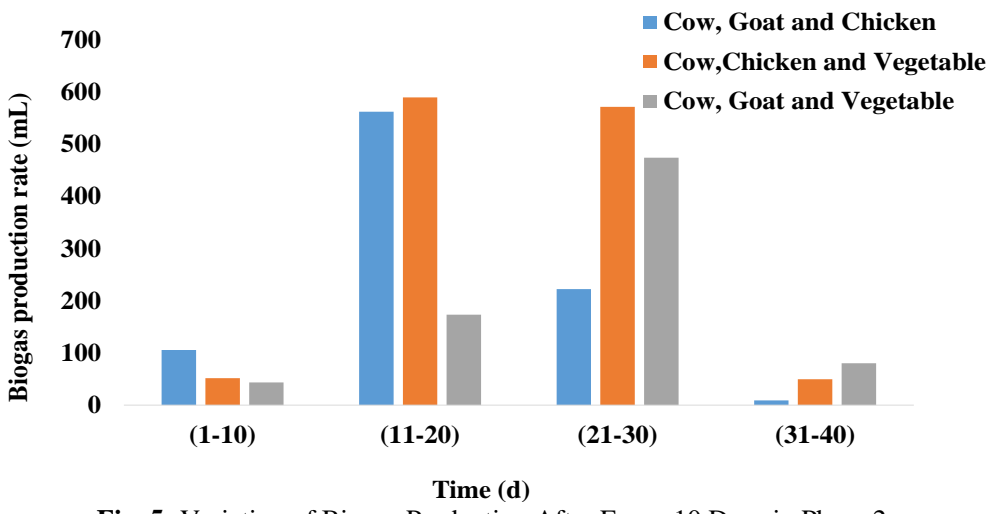

Fig. 5: Variation of Biogas Production After Every 10 Days in Phase 2.

\subsection{Cumulative biogas production profile}

Fig. 6, represent the cumulative biogas production from rumen waste of chicken and goat, cow and chicken, cow and goat and mixed waste. The figure shows that cumulative production of $812 \mathrm{~mL}$ (chicken and goat digesta), $13949 \mathrm{~mL}$ (cow and chicken digesta), $632.4 \mathrm{~mL}$ (cow and goat digesta) and $4662 \mathrm{~mL}$ (mixed waste) was observed in chicken and goat, cow and chicken, cow and goat and mixed waste respectively. Within 40 days of study period biogas production from rumen digesta was increased. The result shows that cumulatively highest production obtained at the last 10 days of study period. The average cumulative production of biogas from chicken and goat, cow and chicken, cow and goat and mixed waste were $480,883,3,282$, and $307,9 \mathrm{~mL} / \mathrm{d}$ respectively.

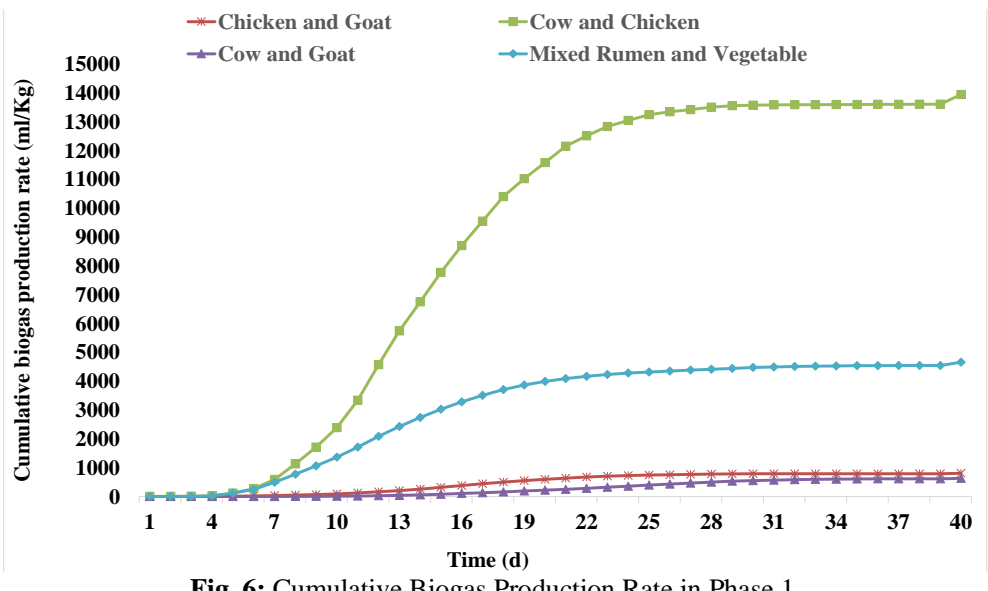

Fig. 6: Cumulative Biogas Production Rate in Phase 1.

Fig. 7, represent the cumulative biogas production from rumen waste of cow, goat and chicken, cow, chicken and vegetable waste and cow, goat and vegetable waste. The figure shows that cumulative production of $901 \mathrm{~mL}, 1294 \mathrm{~mL}$ and $772 \mathrm{~mL}$ was observed in cow, goat and 
chicken, cow, chicken and vegetable and cow, goat and vegetable waste respectively. Within 40 days of study period biogas production from rumen digesta was increased. The result shows that cumulatively highest production obtained at the last 10 days of study period. The average cumulative production of biogas from chicken and goat, cow and chicken, cow and goat and mixed waste were 551, 689, and 341 $\mathrm{mL} / \mathrm{d}$ respectively.

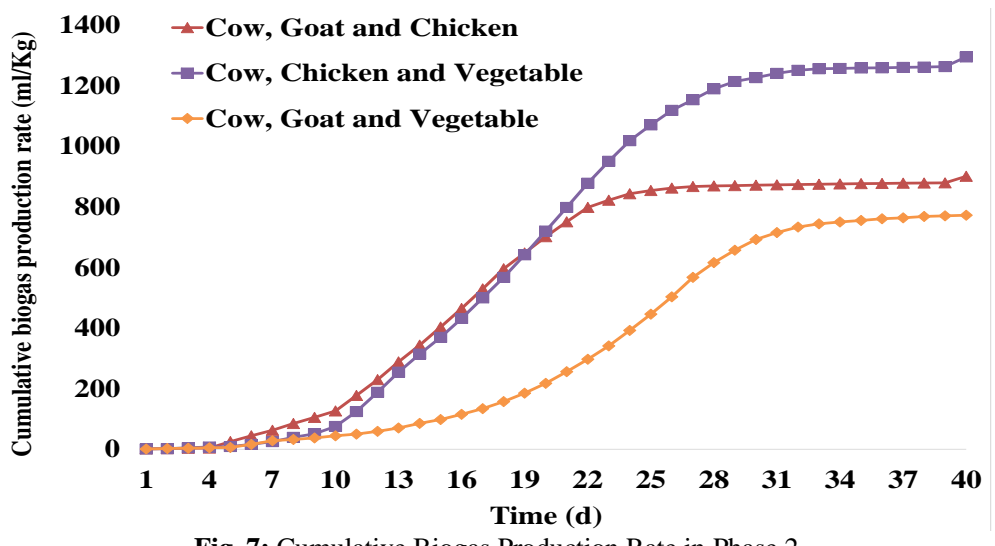

Fig. 7: Cumulative Biogas Production Rate in Phase 2.

\subsection{Temperature profile}

The daily temperature was noted during anaerobic digestion process. The temperature was in mesophilic range during study period. The lowest temperature was $23.5^{\circ} \mathrm{C}$ which was obtained on $3^{\text {rd }}$ operating day in phase 1 and $22.6^{\circ} \mathrm{C}$ which was obtained on $32^{\text {nd }}, 33^{\text {th }}, 34^{\text {th }}, 39^{\text {th }}$ and $40^{\text {th }}$ operating day in phase 2 . The highest temperature was $32.4^{\circ} \mathrm{C}$ which was obtained on $29^{\text {th }}$ operating day in phase 1 and was $27.3^{\circ} \mathrm{C}$ which was obtained on $1^{\text {st }}$ operating day in phase 2 . The average temperature was recorded $27.9^{\circ} \mathrm{C}$ in phase 1 and $24.3^{\circ} \mathrm{C}$ in phase 2 at the end of 40 days digestion time.

\section{Conclusions}

The scarcity of energy will be faced by the world in next few decades due to rapid growth of population. Renewable energy can be used as an alternative source to solve this problem. This study was to assess the enhancement of biogas yield from rumen digesta and kitchen wastes. The digestion of these substrates was conducted in two experiment under different seasons in batch type digestion system. In this study, rumen digesta were successfully digested and generated biogas. The first phase experiment was conducted in summer season and the average production of biogas from rumen digesta of chicken and goat, cow and chicken, cow and goat and cow, chicken, goat and vegetable waste were found 20,340,16 and $113 \mathrm{~mL} / \mathrm{d}$ respectively. The second phase experiment was conducted in winter season and the average production of biogas from rumen digesta of (cow, goat and chicken), (cow, chicken and vegetable) and (cow, goat and vegetable) waste were found 22, 32 and $19 \mathrm{~mL} / \mathrm{d}$ respectively. The data obtained from this study could be used as a basis for treatment of kitchen waste. The digestion of these substrates could be very promising way to provide renewable energy and remove environmental pollution.

\section{Acknowledgements}

The authors would like to give thanks and acknowledge the Agricultural and Biosystems Engineering Lab under the Department of Farm Power and Machinery, Sylhet Agricultural University, Sylhet for this experimentation and help to complete the research work.

\section{Author Contributions}

M.R.A.M. (Professor) has accomplished the research design, supervised, data analyzed and revised the paper. M.M. (MS student) was conducted the work and partially wrote the paper. N.S.U. (MS student) was conducted the work and represented the collected data by graphically. M.J.A.S. (Lecturer) jointly discussed, analyzed best fit data and partially wrote the paper. Finally, all authors approved the final version of the paper.

\section{References}

[1] G. Plaza, P. Robredo, O. Pacheco, and A. S. Toledo, "Anaerobic treatment of municipal solid waste”, Water Sci. Technol., Vol.33, No.3, (1996), pp.169-175. https://doi.org/10.2166/wst.1996.0068.

[2] A. Karagiannidis and G. Perkoulidis, "A multi-criteria ranking of different technologies for the anaerobic digestion for energy recovery of the organic fraction of municipal solid wastes", Bioresour. Technol., Vol.100, (2009), pp.2355-2360. https://doi.org/10.1016/j.biortech.2008.11.033.

[3] M. Poeschl, S. Ward, and P. Owende, "Evaluation of energy efficiency of various biogas production and utilization pathways", Appl. Energy, Vol.87, (2010), pp.3305-3321. https://doi.org/10.1016/j.apenergy.2010.05.011.

[4] G. Berndes, M. Hoogwijk, and R. Broek, "The Contribution of Biomass in the Future Global Energy Supply: A Review of 17 Studies", Biomass and Bioenergy, Vol.25, (2003), pp. 1-28. https://doi.org/10.1016/S0961-9534(02)00185-X.

[5] Y. H. Zheng et al., "Anaerobic fermentation technology increases biomass energy use efficiency in crop residue utilization and biogas production", Renew. Sustain. Energy Rev., Vol.16, No. 7, (2012), pp. 4588-4596. https://doi.org/10.1016/j.rser.2012.03.061.

[6] K. Lee, P. Chantrasakdakul, D. Kim, M. Kong, and K. Y. Park, "Ultrasound pretreatment of filamentous algal biomass for enhanced biogas production”, Waste Manag., Vol.34, No. 6, (2014), pp. 1035-1040. https://doi.org/10.1016/j.wasman.2013.10.012.

[7] Incirenators in Disguise: Case study of gasification, Pyrolisis and Plasma incineration in Europe, Asia and United States, April 2006.

[8] C. Roati, S. Fiore, B. Ruffino, F. Marchese, D. Novarino, and M. C. Zanetti, "Preliminary evaluation of the potential biogas production of foodprocessing industrial wastes", Am. J. Environ. Sci., Vol.8, No. 3, (2012), pp. 291-296. 
[9] Rittmann B and McCarty P, Environmental Biotechnology: Principles and Applications, McGraw-Hill, (2001). https://doi.org/10.2175/193864701790902789.

[10] M. R. Al Mamun and S. Torii, "Anaerobic co-digestion technology in solid wastes treatment for biomethane generation”, Int. J. Sustain. Energy, Vol.36, No. 5, (2017), pp. 462-472. https://doi.org/10.1080/14786451.2015.1043302.

[11] M. R. Al Mamun and S. Torii, "Production of Biomethane from Cafeteria, Vegetable and Fruit Wastes by Anaerobic Co-Digestion Process", J. Clean Energy Technol., Vol.33, (2015), pp. 321-325. https://doi.org/10.7763/JOCET.2015.V3.216.

[12] M. Rouf et al., "Biogas from slaughter house waste and optimization of the process", Bangladesh J. Sci. Ind. Res., Vol.51, (2016), pp. 203-214. https://doi.org/10.3329/bjsir.v51i3.29432.

[13] P. Abdeshahian, J. S. Lim, W. S. Ho, H. Hashim, and C. T. Lee, "Potential of biogas production from farm animal waste in Malaysia", Renew. Sustain. Energy Rev., Vol.60, (2016), pp. 714-723. https://doi.org/10.1016/i.rser.2016.01.117.

[14] S. Salleh, M. Zulkifli, and M. Jalani, "Production of Biogas Using Dairy Manure as Feedstock and Rumen Fluid as Inoculum", J. Appl. Sci. Process Eng., Vol.3, (2016), pp. 83-89. https://doi.org/10.33736/jaspe.310.2016.

[15] O. Christian and C. E. Nwanyanwu, "Biogas Production from Fish Pond Effluent Supplemented with Cow Blood Meal in a Batch Anaerobic Digester System Biogas Production from Fish Pond Effluent Supplemented with Cow Blood Meal in a Batch Anaerobic Digester System", Futo. J. Series (FUTOJNLS)., Vol.3, No. 1, (2017), pp. 166-175.

[16] S. Manimuthu, M., Sathiya Pandi, N., Asha, G., and Rajendran, "The Biogas Production from mixture of Agar and Rumen Wastes", Int. J. Adv. Res., Vol.3, No. 6, (2015), pp. 362-369.

[17] B. I N Widiasa and S. J. Sunarso, "Study on Slaughterhouse Wastes Potency and Characteristic for Biogas Production", Int. J. Waste Resour., Vol.1, No.1, (2015), pp. 4-7.

[18] A. Pertiwinin, E. Susilowati, R., N. Agus Fitri, Y. Soeherman, and M. Fahmi Habi, "Potential Test on Utilization of Cow's Rumen Fluid to Increase Biogas Production Rate and Methane Concentration in Biogas", Asian J. Anim. Sci., Vol.11, No. 2, (2017), pp. 82-87. https://doi.org/10.3923/ajas.2017.82.87.

[19] D. Artanti, R. Saputro, and B. Budiyono, "Biogas Production from Cow Manure", Int. J. Renew. Energy Dev., Vol.1, (2012), pp. 61-64. https://doi.org/10.14710/ijred.1.2.61-64.

[20] Y. Baba, C. Tada, Y. Fukuda, and Y. Nakai, "Improvement of methane production from waste paper by pretreatment with rumen fluid", Bioresour. Technol., Vol.128, (2013), pp. 94-99. https://doi.org/10.1016/j.biortech.2012.09.077.

[21] S. Sunarso, S. Johari, I. Widiasa, and B. Budiyono, "The Effect of Feed to Inoculums Ratio on Biogas Production Rate from Cattle Manure Using Rumen Fluid as Inoculums”, Int. J. Sci. Eng., Vol.1, (2010), pp. 1-4. https://doi.org/10.12777/ijwr.2.1.2012.1-4. 